\title{
The notes on the occurrence of Longidorus poessneckensis Altherr, 1974 (Nematoda: Dorylaimida) in the Slovak Republic
}

\author{
M. LIŠKOVÁ ${ }^{1}$, S. KUMARI ${ }^{2}$ \\ ${ }^{1}$ Parasitological Institute, Slovak Academy of Sciences, Hlinkova 3, 04001 Košice, Slovak Republic, \\ E-mail: liskova@saske.sk; ${ }^{2}$ Crop Research Institute, Division of Plant Health, Drnovská 507, Ruzyně, 16106 Prague 6, \\ Czech Republic
}

\begin{abstract}
Summary
The record of occurrence of Longidorus poessneckensis Altherr, 1974 in forest soils with Betuleto-CarpinetoQuercetum in geographically specific conditions of a hilltop contributes to the broadening of ecological knowledge about this species. To date, the species was considered to prefer the habitats along river banks - narrow or large valleys and plains. The ecological, morphometrical and molecular characteristics of recorded L. poessneckensis are presented here.
\end{abstract}

Keywords: Longidorus poessneckensis, ecology, morphology, molecular characteristic, Slovak Republic

\section{Introduction}

According to current knowledge, the longidorid species Longidorus poessneckensis Altherr, 1974 mostly occurs in permanent or seasonal moist soils with various water courses, soils with woodland, mostly associated with Fraxinetum, Ulmetum and Quercetum or in river banks associated mostly with Alnetum and Salicetum vegetation types. In the European geographical conditions the occurrence of this species is associated with soils derived from river sediments along the River Danube in Slovakia and March in Austria (Lišková \& Sturhan, 2000; Tiefenbrunner \& Tiefenbrunner, 2004 resp.), the Rivers Bodrog, Latorica, Tisa and other rivers in Slovakia (Lišková \& Sturhan, 2000; Lišková, 2001; Lišková \& Čerevková, 2005) and in Germany in soils near or along numerous ri-vers and small brooks (Altherr, 1974; Rau, 1975, 1976; Sturhan, 1995; Sturhan \& Loof, 1995). The most recent information is from the Czech Republic (Kumari et al., 2009) where the species has been found in the rhizosphere of Quercus forest on a plain, probably with higher and fluctuant tailwater level. Surprisingly, this species was found in a soil sample collected from the Betuleto-Carpineto-Quercetum forest on the small upland plain on the top of Dariusova hora hill near the city of Košice in eastern Slovakia. The notes on ecology following from the occurrence of the species $L$. poessneckensis in this unusual site on the hilltop and morphometrical and molecular characteristics of this nematode population are presented here.

\section{Material and methods}

\section{Characteristic of sampling area}

The sampling area is situated in Betuleto-Carpineto-Quercetum forest in the vicinity of Tahanovce village, a suburbs of Košice City $\left(48^{\circ} 44^{\prime} \mathrm{N}, 21^{\circ} 15^{\prime} \mathrm{E}\right)$, an orographic unit of Čierna hora mountains on the boundary with the Košická kotlina basin. Being the part of the Košice Forests, it is not only the logging area, but a green belt serving as a rest area with numerous pathways and cycling routes too. This hilly area has an altitude of about $400 \mathrm{~m}$, with an average annual temperature of $8.4^{\circ} \mathrm{C}$ and annual rainfall of $420 \mathrm{~mm}$. The sampling site was situated in partly moist or wet upland plain on the top of Dáriusova hora hill, with Luvisol or Gleyc Luvisol soil type, clay-loamy soils with sand and gravel admixture of various granularity, soils derived from neogen lacustrine and river sediments. The $\mathrm{pH}$ of the soil was $6.0-7.0$.

\section{Nematological studies}

In May 2009, the soil samples were collected from the depth of app. $20 \mathrm{~cm}$ from the rhizosphere of forest trees $(5$ soil samples from the area of $10 \times 10 \mathrm{~m})$. Soil was then mixed and the nematodes were extracted from $500 \mathrm{~g}$ of the mixed soil using a sieving and decanting method (Brown \& Boag, 1988), fixed by hot TAF and mounted in anhydrous glycerin on slides for examination. Figures were produced using Camera Lucida. 

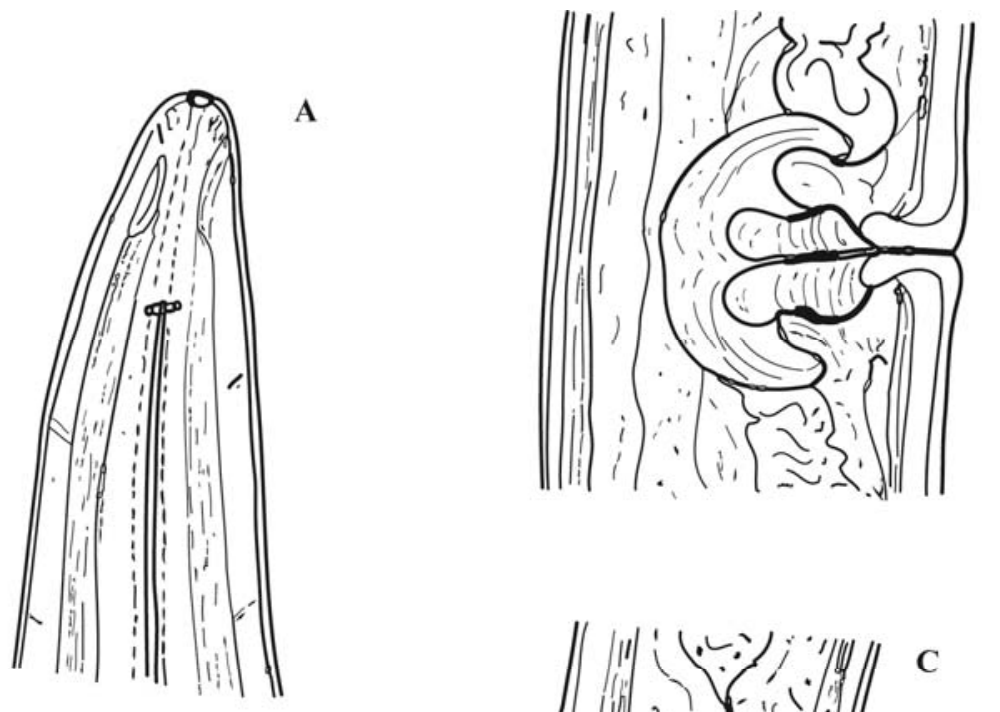

B

$50 \mu \mathrm{m}$
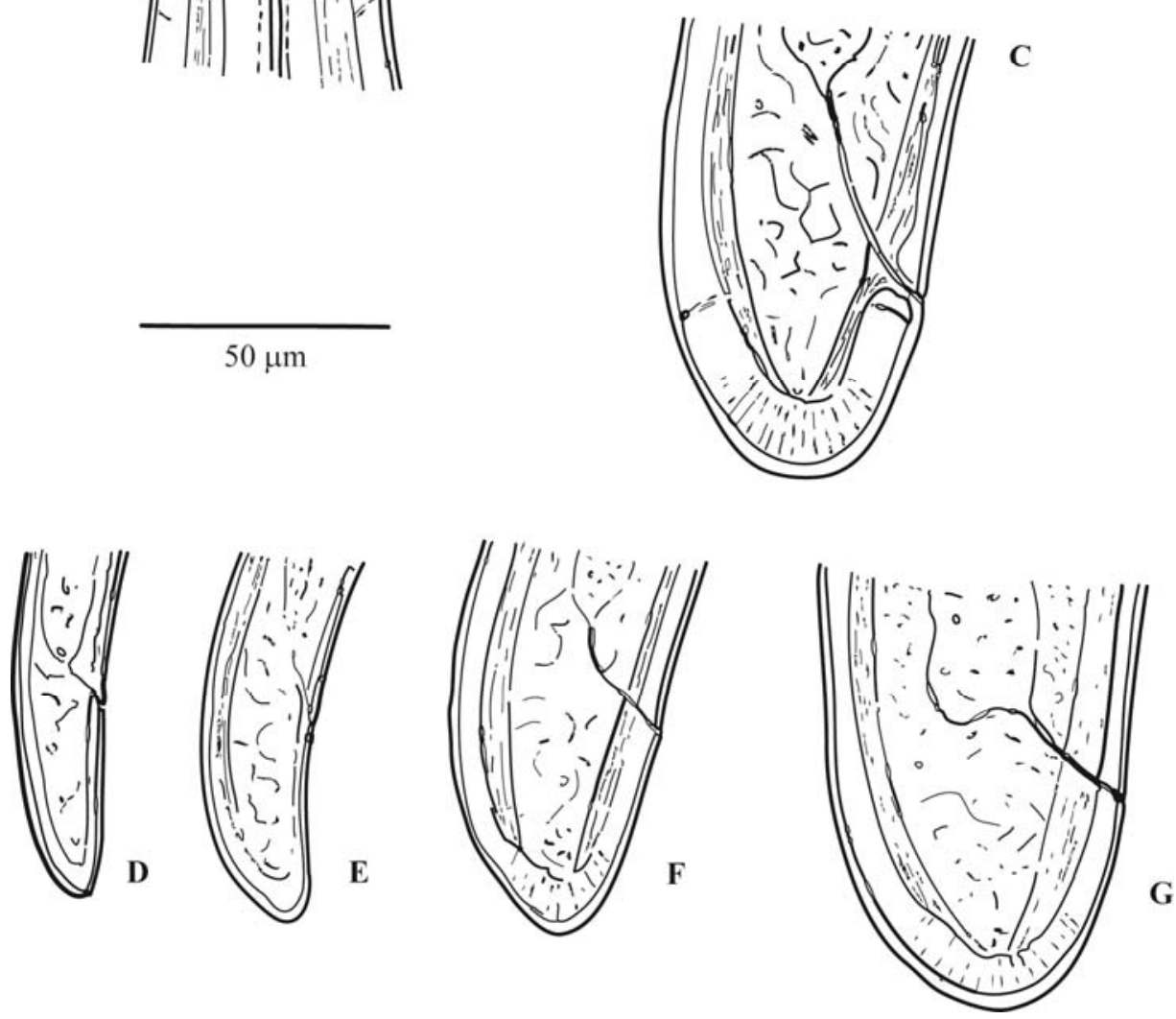

Fig. 1. Longidorus poessneckensis. A - C: Female, A - anterior region; B - vulva region; C - tail;

$\mathrm{D}-\mathrm{G}$ : Tails of juveniles D - J1; E-J2; F-J3; G - J4

A few alive specimens were preserved in $\mathrm{IM} \mathrm{NaCl}$ for sequencing. Temporary mounts of two nematodes were made in a droop of IM NaCl containing glass beads and after taking photomicrographs the slides were dismantled, individual nematodes removed, and added to digest in $0.25 \mathrm{M} \mathrm{NaOH}$ overnight. Total genomic DNA was extracted from these two single individuals using a rapid technique (Stanton et al., 1998). 18S gene of ribosomal DNA was amplified in two overlapping fragments and primer combination was $988 \mathrm{~F}+1912 \mathrm{R}$ for the first fragment and $1813 \mathrm{~F}+2646 \mathrm{R}$ for the second fragment (Holterman et al., 2006). D2/D3 expansion segments of $28 \mathrm{~S}$ gene were amplified using D2A and D3B primers (De Ley et $a l ., 2005)$. PCR assays were performed in a $25 \mu \mathrm{l}$ volume with the following master mix: one PCR bead (GE Healthcare, Buckinghamshire, UK), $20.5 \mu 1$ double distilled sterile water, $2.0 \mu \mathrm{l}$ each primer $(10 \mathrm{pmol} / \mu \mathrm{l})$ and to this $0.5 \mu \mathrm{l}$ of DNA was added as a template for PCR. The cycling conditions were: first denaturation for $3 \mathrm{~min}$ at $94^{\circ} \mathrm{C}, 40$ cycles with $30 \mathrm{~s}$ at $94^{\circ} \mathrm{C}, 30 \mathrm{~s}$ at $55^{\circ} \mathrm{C}, 30 \mathrm{~s}$ at $72^{\circ} \mathrm{C}$ and a final elongation step was run at $72^{\circ} \mathrm{C}$ for 10 min. DNA was purified using High Pure Product Purification kit (Roche Diagnostics GmbH, Manheim, Germany) and directly sequenced in both directions 
(Macrogen, Korea). Sequencher ${ }^{\mathrm{TM}} 4.8$ (Genes Codes. Corp., Ann Arbor, MI, USA) software was used to assemble and view sequences and check for base-calling errors.

\section{Results and discussion}

Notes to ecology

Up to date in Slovakia, the species L. poessneckensis occurred exclusively in geographically low-lying sites, i.e. river banks, smaller or larger riverine plains and valleys. The records were mostly from flooded forests, near rivers or streams with vegetation mostly represented by Fraxinetum, Ulmetum, Quercetum, Alnetum and Salicetum vegetation types. Recently, this species was surprisingly found in the soils sample collected at the hilltop with Betuleto-Carpineto-Quercetum vegetation. A question has arisen concerning the locality. It is possible to speculate about a linkage between geographical distribution of the nematodes and former geological events during which the area was created by neogeon or river sediments and thus this species has been distributed in this enclave - a hilltop. Weischer and Almeida (1995) have emphasized the importance of geological processes for regional distribution of longidorids. Lišková (2001) has expressed the assumptions for association of some individual longidorid species with specific soil type derived from characteristic mother rock of specific geological origin. Moist soil conditions of the sampling site (small upland plain) also support the aforementioned assumptions. The association of $L$. poessneckensis with this type of soil is in an agreement with the observations of Sturhan and Loof (2001), Tiefenbrunner and Tiefenbrunner (2004) and Lišková and Sturhan, (2000), Lišková (2001), Lišková and Čerevková (2005).

\section{Notes to morphology}

(Fig. 1, A-G, Fig. 2, A - D)

The morphometric parameters of females and four larval stages are presented in Table 1. Males were not observed. It is necessary to note that during sampling time in May a surprisingly high portion of L1 was observed (about $30 \%$ out of all specimens). This is especially important as during previous investigations we have had difficulties to collect sufficient amount of L1 for a morphometric study. Comparing the current data on the population with the previously obtained data from Slovakia (Lišková \& Sturhan, 2000), Austria (Tiefenbrunner \& Tiefenbrunner, 2004), Germany (Altherr, 1974; Rau, 1975, 1976; Sturhan, 1995; Sturhan \& Loof, 2001) and from the Czech Republic (Kumari et al., 2009) there are some little variations in several morphometric parameters. For instance the L, a, b, c, the length, body size and odontostyle of females and other parameters differ slightly from an original description given by Altherr (1974), but they agree well with data in ,redescription of the species“" given by Sturhan and Loof
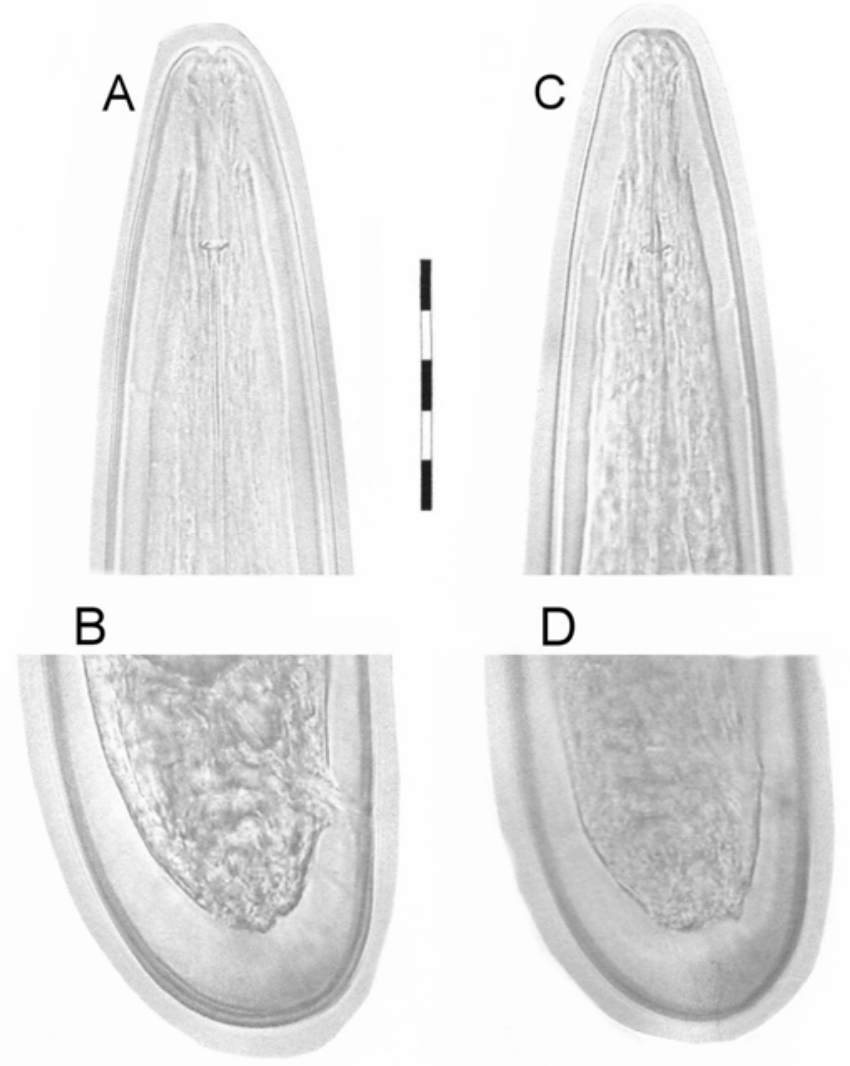

Fig. 2. Longidorus poessneckensis - specimens used for sequencing. A, B: Anterior and posterior region of first individual; C. D: Anterior and posterior region of second individual (Scale bar - 50um) 
Table 1. Morphometrics of Longidorus poessneckensis (all measurements in $\mu \mathrm{m}$, except $\mathrm{L}$ in $\mathrm{mm}$ )

\begin{tabular}{|c|c|c|c|c|c|}
\hline \multirow{3}{*}{$\begin{array}{l}\text { Locality } \\
\text { Host } \\
\text { Stage }\end{array}$} & \multicolumn{5}{|c|}{ Ťahanovce near Košice City } \\
\hline & \multicolumn{5}{|c|}{ Betuleto-Carpineto-Quercetum } \\
\hline & $\mathrm{J} 1$ & $\mathrm{~J} 2$ & $\mathrm{~J} 3$ & $\mathrm{~J} 4$ & Females \\
\hline $\mathrm{n}$ & 15 & 11 & 14 & 9 & 9 \\
\hline $\mathrm{L}$ & $\begin{array}{c}1.49 \pm 0.08 \\
(1.39-1.70)\end{array}$ & $\begin{array}{c}2.39 \pm 0.32 \\
(2.07-3.17)\end{array}$ & $\begin{array}{c}3.57 \pm 0.52 \\
(2.90-4.56)\end{array}$ & $\begin{array}{c}4.82 \pm 0.46 \\
(4.38-5.78)\end{array}$ & $\begin{array}{c}6.69 \pm 0.46 \\
(6.01-7.36)\end{array}$ \\
\hline $\mathrm{a}$ & $\begin{array}{c}57.6 \pm 4.70 \\
(53.3-63.3) \\
\end{array}$ & $\begin{array}{c}61.7 \pm 7.40 \\
(52.3-72.8) \\
\end{array}$ & $\begin{array}{c}71.2 \pm 6.99 \\
(60.4-87.6) \\
\end{array}$ & $\begin{array}{c}78.3 \pm 7.66 \\
(71.6-85.0) \\
\end{array}$ & $\begin{array}{c}90.8 \pm 7.24 \\
(75.2-99.2) \\
\end{array}$ \\
\hline $\mathrm{b}$ & $\begin{array}{l}5.2 \pm 0.98 \\
(4.0-7.6)\end{array}$ & $\begin{array}{l}6.9 \pm 1.18 \\
(5.5-9.6)\end{array}$ & $\begin{array}{l}8.1 \pm 0.92 \\
(6.5-9.7)\end{array}$ & $\begin{array}{c}9.9 \pm 1.28 \\
(8.8-12.6)\end{array}$ & $\begin{array}{c}11.8 \pm 0.94 \\
(10.5-13.0)\end{array}$ \\
\hline $\mathrm{c}$ & $\begin{array}{c}37.8 \pm 2.63 \\
(33.5-41.7)\end{array}$ & $\begin{array}{c}54.0 \pm 5.40 \\
(47.5-66.0)\end{array}$ & $\begin{array}{c}84.3 \pm 16.29 \\
(71.2-111.0)\end{array}$ & $\begin{array}{c}112.8 \pm 11.28 \\
(100.5-134.4)\end{array}$ & $\begin{array}{c}158.6 \pm 13.12 \\
(142.7-186.3)\end{array}$ \\
\hline $\mathrm{c}^{\prime}$ & $\begin{array}{c}2.03 \pm 0.20 \\
(1.79-2.50)\end{array}$ & $\begin{array}{c}1.41 \pm 0.13 \\
(1.20-1.69)\end{array}$ & $\begin{array}{c}1.04 \pm 0.21 \\
(0.82-1.69)\end{array}$ & $\begin{array}{c}0.90 \pm 0.13 \\
(0.73-1.10)\end{array}$ & $\begin{array}{c}0.78 \pm 0.05 \\
(0.69-0.85)\end{array}$ \\
\hline $\mathrm{V}(\%)$ & - & - & - & - & $\begin{array}{c}53.1 \pm 1.40 \\
(50.4-55.0)\end{array}$ \\
\hline Odontostyle & $\begin{array}{c}69.3 \pm 2.30 \\
(66.0-72.0)\end{array}$ & $\begin{array}{c}82.6 \pm 3.15 \\
(72.0-88.0)\end{array}$ & $\begin{array}{c}109.2 \pm 7.60 \\
(98.0-120.0)\end{array}$ & $\begin{array}{c}126.6 \pm 3.92 \\
(120.0-136.0)\end{array}$ & $\begin{array}{c}140.2 \pm 4.47 \\
(132.0-148.0)\end{array}$ \\
\hline Odontophore & $\begin{array}{c}38.6 \pm 1.93 \\
(36.0-42.0)\end{array}$ & $\begin{array}{c}42.0 \pm 1.63 \\
(40.0-44.0)\end{array}$ & $\begin{array}{c}48.4 \pm 8.83 \\
(36.0-57.0)\end{array}$ & $\begin{array}{c}52.7 \pm 8.83 \\
(48.0-68.0)\end{array}$ & $\begin{array}{l}68.3 \pm 11.10 \\
(53.0-80.0)\end{array}$ \\
\hline Replacement odontostyle & $\begin{array}{c}77.8 \pm 3.12 \\
(71.0-80.0)\end{array}$ & $\begin{array}{c}103.6 \pm 5.82 \\
(96.0-116.0)\end{array}$ & $\begin{array}{c}122.5 \pm 4.42 \\
(112.0-128.0)\end{array}$ & $\begin{array}{c}136.0 \pm 4.14 \\
(130.0-141.0)\end{array}$ & - \\
\hline Oral aperture to guide ring & $\begin{array}{c}19.1 \pm 0.92 \\
(16.8-20.0)\end{array}$ & $\begin{array}{c}24.4 \pm 1.12 \\
(23.0-27.6)\end{array}$ & $\begin{array}{c}30.6 \pm 2.21 \\
(28.0-33.0)\end{array}$ & $\begin{array}{c}36.1 \pm 1.52 \\
(34.0-38.0)\end{array}$ & $\begin{array}{c}39.6 \pm 1.26 \\
(38.0-40.0)\end{array}$ \\
\hline Tail length & $\begin{array}{c}39.5 \pm 2.32 \\
(36.0-44.0)\end{array}$ & $\begin{array}{c}44.2 \pm 1.40 \\
(40.0-49.0)\end{array}$ & $\begin{array}{c}43.3 \pm 3.27 \\
(36.0-48.0)\end{array}$ & $\begin{array}{c}42.8 \pm 1.62 \\
(40.0-44.0)\end{array}$ & $\begin{array}{c}42.3 \pm 3.03 \\
(36.0-44.0)\end{array}$ \\
\hline Length of hyaline tip $\mathrm{J}$ & $\begin{array}{l}7.3 \pm 0.92 \\
(5.8-8.4)\end{array}$ & $\begin{array}{c}7.2 \pm 1.40 \\
(5.0-10.0)\end{array}$ & $\begin{array}{l}10.4 \pm 1.63 \\
(8.0-12.0)\end{array}$ & $\begin{array}{l}11.6 \pm 2.22 \\
(9.0-15.8)\end{array}$ & $\begin{array}{c}16.1 \pm 2.31 \\
(13.0-20.0)\end{array}$ \\
\hline Body diameter at lip region & $\begin{array}{l}6.9 \pm 0.56 \\
(6.5-8.0)\end{array}$ & $\begin{array}{l}7.7 \pm 0.70 \\
(7.0-8.8)\end{array}$ & $\begin{array}{l}10.3 \pm 1.18 \\
(8.0-12.0)\end{array}$ & $\begin{array}{c}11.6 \pm 0.83 \\
(11.0-13.0)\end{array}$ & $\begin{array}{c}14.7 \pm 0.82 \\
(14.0-16.0)\end{array}$ \\
\hline Body diam. at guid. ring & $\begin{array}{c}14.3 \pm 1.03 \\
(12.5-16.0)\end{array}$ & $\begin{array}{c}16.7 \pm 1.67 \\
(15.5-20.0)\end{array}$ & $\begin{array}{c}22.9 \pm 1.77 \\
(20.0-26.0)\end{array}$ & $\begin{array}{c}27.1 \pm 1.97 \\
(24.0-30.0)\end{array}$ & $\begin{array}{c}31.1 \pm 1.79 \\
(28.0-33.2)\end{array}$ \\
\hline Body diam. at base of oesophagus & $\begin{array}{c}25.5 \pm 2.61 \\
(24.0-32.0)\end{array}$ & $\begin{array}{c}36.7 \pm 3.86 \\
(30.4-43.0)\end{array}$ & $\begin{array}{c}45.9 \pm 3.17 \\
(42.0-52.0)\end{array}$ & $\begin{array}{c}54.5 \pm 5.16 \\
(46.0-60.0)\end{array}$ & $\begin{array}{c}61.2 \pm 2.93 \\
(56.0-64.8)\end{array}$ \\
\hline Body diam. at mid body/vulva & $\begin{array}{c}26.18 \pm 3.13 \\
(24.0-32.0)\end{array}$ & $\begin{array}{c}39.1 \pm 4.55 \\
(32.0-47.0)\end{array}$ & $\begin{array}{c}50.8 \pm 6.39 \\
(38.5-64.0)\end{array}$ & $\begin{array}{c}63.0 \pm 5.58 \\
(54.0-68.0)\end{array}$ & $\begin{array}{c}73.8 \pm 4.67 \\
(64.0-80.0)\end{array}$ \\
\hline Body diam. at anus & $\begin{array}{c}19.6 \pm 1.45 \\
(16.0-22.8)\end{array}$ & $\begin{array}{c}31.2 \pm 1.39 \\
(23.0-40.0)\end{array}$ & $\begin{array}{c}43.6 \pm 2.69 \\
(39.5-48.0)\end{array}$ & $\begin{array}{c}53.6 \pm 5.46 \\
(48.0-65.0)\end{array}$ & $\begin{array}{c}54.6 \pm 3.05 \\
(48.0-58.0)\end{array}$ \\
\hline Body diam. at beginning of $\mathrm{J}$ & $\begin{array}{c}12.1 \pm 0.92 \\
(10.0-12.2)\end{array}$ & $\begin{array}{c}17.7 \pm 2.31 \\
(14.0-20.0)\end{array}$ & $\begin{array}{c}29.9 \pm 3.35 \\
(26.0-36.0)\end{array}$ & $\begin{array}{c}36.9 \pm 3.54 \\
(30.0-40.0)\end{array}$ & $\begin{array}{c}41.8 \pm 2.52 \\
(36.0-44.0)\end{array}$ \\
\hline
\end{tabular}

(2001) and with those from the Czech Republic (Kumari et al., 2009). The most noticeable differences observed in the population from our sampling site (the hilltop of Dáriusova hora) are morphometric parameters of L1. The L1 larvae were of smaller size (some below $1.40 \mathrm{~mm}$ ) with a shorter odontostyle $(66 \mu \mathrm{m})$ and $\mathrm{c}^{\prime}=2.50$ (in comparison to maximum c' from the Czech Republic 1.91 and from Germany 2.2), meaning that at some populations the L1 can be characterized by a larger and a slightly conical rounded tail (Fig. 1 D).

\section{Notes to molecular analysis}

Head and tail shape of the two specimens used for sequencing is presented in Fig. 2. The D2/D3 expansion segments of $28 \mathrm{~S}$ gene and $18 \mathrm{~S}$ gene of ribosomal DNA were sequenced from these two single individuals. Identical sequences were obtained for both individuals for each gene. The obtained sequences were compared by Basic Local Alignment Search Tool (BLAST) in National Center for Biotechnology Information (NCBI) and the result showed $100 \%$ identity with $L$. poessneckensis accession number EF538750 for D2/D3 and accession number EF538745 for $18 \mathrm{~S}$ gene. 


\section{Acknowledgements}

The study was supported by VEGA Scientific Grant Agency, Grant No. 2/0136/10.

\section{References}

AlTHERR, F. (1974): Nématodes de la nappe phréatique du réseau de la Saale (Thuringe) II. Limnologica, 9: 81 - 132 Brown, D. J. F., BoAG, B. (1988): An examination of methods used to extract virus-vector nematodes (Nematoda: Longidoridae and Trichodoridae) from soil samples. Nematol. mediterr., 16: 93 - 99

De Ley, P., FÉliX, M. A., Frisse, L. M., NAdler, S. A., SternberG, P. W., Thomas, W. K. (1999): Molecular and morphological characterisation of two reproductively isolated species with mirror-image anatomy (Nematoda: Cephalobidae). Nematology, 1: $591-612$

Holterman, M., Wurff, A. V. D., Elsen, S. V. D., Megen, H. V., Bongers, T., HolOVACHOV, O., BAKKER, J., HELDER, J. (2006): Phylum-wide analysis of SSU rDNA reveals deep phylogenetic relationships among nematodes and accelerated evolution toward crown clades. Molec. Biol. Evol., 23: 1792 - 1800. DOI: 10.1093/molbev/mls044

Kumari, S., Decraemer, W., Traversa, D., LiŠKOVÁ, M. (2009): Molecular and morphological delineation of Longidorus poessneckensis Altherr, 1974 (Nematoda: Dorylaimida). Eur. J. Plant Pathol., 123: 125 - 137. DOI: 10.10 07/s10658-008-9348-4

LIŠKOVÁ, M. (2001): Longidoridae (Nematoda: Dory- laimida) in natural grassland of fluvial plains and river banks in the Slovak Republic. Helminthologia, 38: $47-50$ LIŠKOVÁ, M., STURHAN, D. (2000): Occurrence and ecology of Longidoridae (Nematoda: Dorylaimida) in floodplain forests in the Slovak Republic. Helminthologia, 37: 113 - 117 LiŠKOVÁ, M., ČEREVKOVÁ, A. (2005): Nematode communities of river banks and adjacent meadows in the Slovak Republic. Helminthologia, 42: 223 - 232

RAU, J. (1976): Das Vorkommen virusübertragender Nematoden in naturnahen Waldgesellschaften Niedersachsens. Z. angew. Zool., 63: $427-443$

RAU, J. (1975): Das Vorkommen virusübertragender Nematoden in ungestörten Biotopen Niedersachsens. Dissertation, Technische Universität, Hannover, 169p.

Stanton, J. M., McNicol, C. D., Steele, V. (1998): Nonmanual lysis of second-stage Meloidogyne juveniles for identification of pure and mixed samples based on the polymerase chain reaction. Australas. Plant Path., 27: $112-115$ Sturhan, D., LoOF, P.A.A. (2001): Redescription of Longidorus poessneckensis Altherr, 1974 (Nematoda: Dorylaimida). Russ. J. Nematol., 9: 43 - 49

STURHAN, D. (1995): Distribution of virus-vector nematodes in Germany. Nematologica, 41: 345

Tiefenbrunner, A., Tiefenbrunner, W. (2004): Longidoridae (Nematoda: Dorylaimida) from the rhizosphere of wild growing grape (Vitis vinifera ssp. silvestris) in the riparian woods of the rivers Danube and Marchs in Austria. Helminthologia, 41: $45-53$

Weischer, B., Almeida M., T. (1995): Ecology of longidorid nematodes. Russ. J. Nematol., 3: $9-21$ 